\title{
Identification of sources of elevated concentrations of polycyclic aromatic hydrocarbons in an industrial area in Tianjin, China
}

\author{
Wentao Jiao • Yonglong Lu • Jing Li • \\ Jingyi Han · Tieyu Wang • Wei Luo • \\ Yajuan Shi · Guang Wang
}

Received: 26 December 2007 / Accepted: 10 October 2008 / Published online: 3 January 2009

(C) Springer Science + Business Media B.V. 2008

\begin{abstract}
The concentrations of 16 polycyclic aromatic hydrocarbons (PAHs) were determined by gas chromatography equipped with a mass spectrometry detector in 105 topsoil samples from an industrial area around Bohai Bay, Tianjin in the North of China. Results demonstrated that concentrations of PAHs in 104 soil samples from this area ranged from 68.7 to $5,590 \mathrm{ng} \mathrm{g}^{-1}$ dry weight with a mean of $\sum 16$ PAHs $814 \pm 813 \mathrm{ng} \mathrm{g}^{-1}$, which suggests that there exists mid to high levels of PAH contamination. The concentration of $\sum 16$ PAHs in one soil sample from Tianjin Port was exceptionally high $\left(48,700 \mathrm{ng}^{-1}\right)$. Ninetythree of the 105 soil samples were considered to be contaminated with PAHs $\left(>200 \mathrm{ng} \mathrm{g}^{-1}\right)$, and 25 were heavily polluted $\left(>1,000 \mathrm{ng} \mathrm{g}^{-1}\right)$. The sites with high PAHs concentration are mainly distrib-
\end{abstract}

W. Jiao · Y. Lu (ه) · J. Li · J. Han · T. Wang .

W. Luo · Y. Shi · G. Wang

State Key Laboratory of Urban and Regional Ecology, Research Center for Eco-Environmental Sciences, Chinese Academy of Sciences, Beijing 100085, China e-mail: yllu@rcees.ac.cn

W. Jiao $\cdot$ Y. Lu $\cdot$ J. Li $\cdot$ G. Wang

Graduate University of Chinese Academy of Sciences, Beijing 100039, China

\section{J. Han}

Environmental Policy Group, Wageningen University, 6706 KN, Wageningen, The Netherlands uted around chemical industry parks and near highways. Two low molecular weight PAHs, naphthalene and phenanthrene, were the dominant components in the soil samples, which accounted for $22.1 \%$ and $10.7 \%$ of the $\sum 16$ PAHs concentration, respectively. According to the observed molecular indices, house heating in winter, straw stalk combustion in open areas after harvest, and petroleum input were common sources of PAHs in this area, while factory discharge and vehicle exhaust were the major sources around chemical industrial parks and near highways. Biological processes were probably another main source of low molecular weight PAHs.

Keywords PAHs • Distribution •

Chemical industrial parks • Soil contamination • Tianjin Binhai New Area

\section{Introduction}

Polycyclic aromatic hydrocarbons (PAHs) are a group of organic compounds with two or more fused aromatic rings and are widespread throughout environmental media (Edwards 1983; Mielke et al. 2001; Wu et al. 2005). Because of their toxic, mutagenic, and carcinogenic characteristics, 16 PAHs have been listed as priority pollutants by the US Environmental Protection Agency (USEPA) and studied by scientists all over the 
world (Kipopoulou et al. 1999; Nadal et al. 2004; Wang et al. 2007). PAHs arise from natural and anthropogenic emissions, such as the incomplete combustion of organic matter, emissions of noncombustion-derived petrogenic, natural petroleum seeps, and as products of biogenic transformations (Edwards 1983; Wilcke 2007). To assess the dominant origins of PAHs, molecular indices based on the ratios of individual $\mathrm{PAH}$ levels in soil have commonly been used, such as benzo[a]anthracene/(benzo[a]anthracene + chrysene) and fluoranthene/(pyrene + fluoranthene) congener ratios (Yunker et al. 2002).

Once PAHs are released into the atmosphere, they are subject to sink into soil via dry and wet deposition. Due to their high hydrophobic properties and relatively stable chemical structures, PAHs partition to particle surfaces, especially on the organic part, and accumulate in soils and sediments. Accumulation of PAHs in soils may lead to contamination of food chains (Kipopoulou et al. 1999). Leakage, evaporation, and migration of PAHs from soils are possible sources of atmospheric and groundwater contamination (Cousins et al. 1999).

Over the last decade, China has experienced rapid economic development and urbanization, which have severely deteriorated the environmental quality, especially along the coast. Tianjin Binhai New Area (TBNA) is one of the most important industrial areas in the North of China, situated in the lower portion of the Haihe River watershed and west of Bohai Bay. The gross output of TBNA's industries reached 196 billion Yuan (about US $\$ 28.6$ billion) in 2006, which was about 19 times of that in 1993. Reports have shown that PAHs are present in various environmental media in TBNA, and the highest concentration of PAHs in soil samples from TBNA exceeded 5,000 ng $\mathrm{g}^{-1}$ (Duan et al. 2005; Shi et al. 2005; Wu et al. 2005); however, the industrial influence and regional difference in this area are unclear. There are three districts in TBNA from north to south: Hangu, Tanggu, and Dagang. The industrial development levels and major industries of these three districts are significantly different, which makes it an ideal area to understand the contaminant loadings and influence of industrialization.
The main objective of this study is to determine the concentrations and to explore the characteristics and possible sources of the 16 EPA priority PAHs in TBNA soils and to provide information for regulatory action concerning PAHs pollution in industrial soils.

\section{Materials and methods}

Description of study area

TBNA $\left(38^{\circ} 40^{\prime}-39^{\circ} 00^{\prime} \mathrm{N}\right.$ and $\left.117^{\circ} 20^{\prime}-118^{\circ} 00^{\prime} \mathrm{E}\right)$ is located at the intersection of the Beijing-TianjinHebei economic zone and the center of the Bohai Bay Rim city belt, in Eastern Tianjin, China. TBNA lies in the warm temperate zone, with maritime feature of warm temperate continental monsoon climate. The southwest wind is prevailing, and average wind speed is $2 \sim 4 \mathrm{~m} / \mathrm{s}$. Mean annual precipitation is between 520 and $660 \mathrm{~mm}$. The average annual temperature is between $11.4^{\circ} \mathrm{C}$ and $12.9^{\circ} \mathrm{C}$. Of the three districts of TBNA, Tanggu is the most urbanized and industrialized, followed by Hangu and Dagang. The coastal chemical industry plays a major role in the economic activity of Tanggu and Hangu. Dagu Chemical Industry Park and Hangu Chemical Industrial Park are in Tanggu and Hangu, respectively. These locations have many older factories that rely on coal for energy. For example, the Tianjin Soda Plant, established in 1917, is well known as the cradle of the Chinese soda industry and the base of the modern chemical industry in China. The Tianjin Chemical Plant is a large sized Alkali-Chlorine enterprise founded in 1938. Furthermore, Tianjin Port, the second largest port in China, is located in Tanggu. In Hangu and Dagang, agriculture is more common than in Tanggu. After harvest, straw stalks are usually burned in the open air. The petrochemical industry has been predominant in the economic development of Tanggu and Dagang, which is one of the petro-chemical industry bases in China.

A significant increase in the number of cars over the past decade, especially in Tanggu District, and coal used to heat houses in winter are potential sources of PAHs in the area. 
Soil sampling and preparation

Surface soil samples $(0-20 \mathrm{~cm})$ were collected from Hangu $(n=38)$, Tanggu $(n=39)$, and Dagang $(n=28)$, in Oct 2006. The sampling locations covered the entire area, with a relatively uniform distribution (Fig. 1). Each sample was a composite of subsamples taken from the top $20 \mathrm{~cm}$ of five sites to obtain a representative sample and was mixed, dried at room temperature (Nadal et al. 2004), sieved through 100-mesh sieve, and stored in glass bottles prior to analysis. Site descriptions were recorded at the time of sampling with land use type and major environmental features included. To eliminate direct effects of vehicle exhaust emissions, the samples were collected at least $50 \mathrm{~m}$ from nearby highways and roads. Some sampling sites were selected on purpose to cover specific contamination sources such as chemical factories.

Standards of 16 USEPA priority PAHs (naphthalene (Nap), acenaphthylene (Acy), acenaphthene (Ace), fluorine ( $\mathrm{Fl})$, phenanthrene (Phe), anthracene (An), fluoranthene (Flu), pyrene (Pyr), benzo[a]anthracene (BaA), chrysene (Chr), benzo[b]fluoranthene(BbF), BENZO[k]fluoranthene $(\mathrm{BkF})$, benzo[a]pyrene $(\mathrm{BaP})$, indeno[1,2,3- cd]pyrene (Inp), dibenzo[a,h]anthracene (DBA), and benzo[ghi]perylene $(\mathrm{BgP}))$ in a mixture solution of 2,000 $\mathrm{ng} \mathrm{g}^{-1}$ and surrogate standard phenanthrene- $d_{10}$ were purchased from Supelco (Bellefonte, PA, USA). Sodium sulfate was baked at $450^{\circ} \mathrm{C}$ for $12 \mathrm{~h}$ and stored in sealed containers. All organic solvents were analytical grade obtained from J.T. Baker Co. (USA). All glassware were immersed with $\mathrm{K}_{2} \mathrm{CrO}_{4}-\mathrm{H}_{2} \mathrm{SO}_{4}$ solution, then washed with tap water and rinsed with redistilled water, and finally dried at $110^{\circ} \mathrm{C}$ before use.

Sample extraction and fractionation

Soil samples (about $5.0 \mathrm{~g}$ ) were mixed with anhydrous sodium sulfate $(2 \mathrm{~g})$ and activated copper slice (1 g) and extracted with a Soxhlet apparatus. Each sample was spiked with a surrogate standard, phenanthrene-d10, and then extracted with $210 \mathrm{ml}$ of methylene chloride for $48 \mathrm{~h}$. The extract was preconcentrated to $2 \mathrm{ml}$ by a rotary evaporator and solvent-exchanged to hexane. The hexane extract was fractionated and cleaned by a silica gel column (Supelco, Bellefonte, PA, USA). Sodium sulfate $(1 \mathrm{~cm})$ was added to the top of silica gel. The column was eluted with $n$-hexane
Fig. 1 Map of the sampling sites in Tianjin Binhai New Area

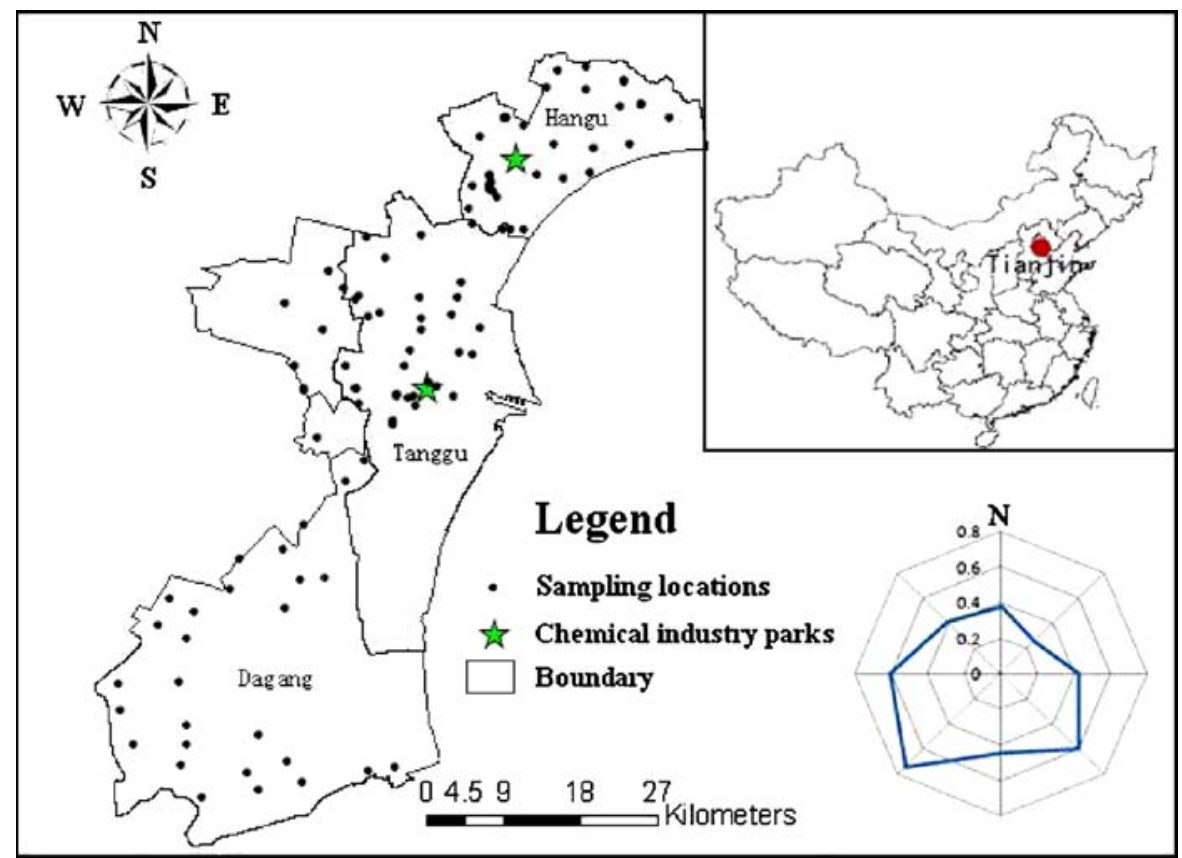


and $5 \mathrm{ml}$ of methylene chloride/hexane $(v / v=3: 7)$ to obtain PAHs. The PAH fraction was finally concentrated to $1 \mathrm{ml}$ under a gentle stream of nitrogen.

\section{PAHs analysis}

The concentrations of PAHs in the extracts were determined using an Agilent 6890 GC equipped with a 5973 mass selective detector under the selected ion monitoring mode (SIM). A HP-5 silica fused capillary column $(60 \mathrm{~m} \times 0.25 \mathrm{~mm}$ inner diameter $\times 0.25 \mu \mathrm{m}$ film thickness) was used with helium as the carrier gas at a constant flow rate of $1 \mathrm{ml} / \mathrm{min}$. Splitless injection of $1 \mu \mathrm{l}$ of the sample was made with an autosampler. The GC oven temperature was programmed to increase from $50^{\circ} \mathrm{C}(2 \mathrm{~min})$ to $200^{\circ} \mathrm{C}(2 \mathrm{~min})$ at $20^{\circ} \mathrm{C} / \mathrm{min}$, then to $240^{\circ} \mathrm{C}(2 \mathrm{~min})$ at $5^{\circ} \mathrm{C} / \mathrm{min}$ before reaching $290^{\circ} \mathrm{C}$ at $3^{\circ} \mathrm{C} / \mathrm{min}$ and held for $15 \mathrm{~min}$. The injector and detector temperatures were $280^{\circ} \mathrm{C}$ and $300^{\circ} \mathrm{C}$, respectively. Mass spectra were acquired in the electron ionization mode with an electron multiplier voltage of $906 \mathrm{eV}$. Before sample analyses, the instrument was tuned daily with decafluorotriphenylphosphine. PAHs in the samples were identified by the retention time and the abundance of quantification ions or confirmation ions with respect to authentic PAH standards. Automated library searching was performed using the National Institute of Standards and Technology (NIST) Mass Spectral Database. Quantification was made using a five-point calibration curve for individual components. Detection limits were 1.7$4.9 \mathrm{ng} \mathrm{g}^{-1}$ dry weight for PAHs (Nap, $1.8 \mathrm{ng} \mathrm{g}^{-1}$; Acy, $2.2 \mathrm{ng} \mathrm{g}^{-1}$; Ace, $1.8 \mathrm{ng} \mathrm{g}^{-1}$; Fl, $1.7 \mathrm{ng} \mathrm{g}^{-1}$; Phe, 2.2 ng g $^{-1}$; An, 2.9 ng g $^{-1}$; Flu, 3.7 ng g $^{-1}$; Pyr, $3.1 \mathrm{ng} \mathrm{g}^{-1}$; BaA,3.6 ng g ${ }^{-1}$; Chr, $3.4 \mathrm{ng} \mathrm{g}^{-1}$; BbF, $2.6 \mathrm{ng} \mathrm{g}^{-1}$; BkF, $4.9 \mathrm{ng} \mathrm{g}^{-1}$; BaP, 3.9 ng g ${ }^{-1}$; Inp, $4.7 \mathrm{ng} \mathrm{g}^{-1}$; DBA, $3.5 \mathrm{ng} \mathrm{g}^{-1}$; and BgP, $2.7 \mathrm{ng} \mathrm{g}^{-1}$ ). All the results are expressed on a dry weight basis.

\section{Quality assurance and quality control}

Laboratory quality control procedures included analyses of method blanks (solvent), spiked blanks (standards spiked into solvent), matrix spikes or matrix spike duplicates, and sample duplicates. Instrument stability and response were checked using NIST standard solutions. The instruments were calibrated daily, and the relative percentage differences between the five-point calibration and the daily calibrations were $<20 \%$ for all of the target analyses. The recoveries of surrogate standards fell within a narrow range and, for individual PAHs, it was between $58.7 \pm$ $7.4 \%$ and $96.3 \pm 5.8 \%$.

Statistical analysis

SPSS 12.0 for windows was employed for statistical analysis. Pearson correlation analysis was performed to determine if there was statistically significant correlation between the compounds of PAHs, and each district was a group, Hangu $(n=38)$, Tanggu $(n=38$, except the data from Tianjin Port), and Dagang $(n=28)$. The level of significance was set at $P<0.05$ (two-tailed). The software used for mapping the sampling sites was ArcGis (ESRI, US). An interpolation method called Ordinary Kriging was adopted for the interpolation of geographical data.

\section{Results and discussion}

\section{Soil PAHs concentration in TBNA}

Table 1 shows the concentrations of total PAHs (sum of 16 priority PAHs, $\sum 16 \mathrm{PAHs}$ ) and individual PAHs in 104 soil samples from TBNA, excluding one sample from Tianjin Port. Acy was not detectable in sampling sites, and the detectable ratio (DR) of Ace was only $9.62 \%$. The DR of the other 14 PAHs was all above $77 \%$, and Pyr and Chr were detectable in all samples. The DR of the carcinogenic PAH compounds were all above $90 \%$.

PAH concentrations varied considerably among the soil samples. $\sum$ PAHs in one sample from Tianjin Port was exceptionally high at $48,700 \mathrm{ng} \mathrm{g}^{-1}$ dry weight (d.w.) and close to the $\sum$ PAHs maximum of $40,692 \mathrm{ng} \mathrm{g}^{-1}$ reported for sediment from the port of New Orleans (Mielke et al. 2001). This indicates that the soil sample from Tianjin Port was heavily polluted. Tianjin Port is the second largest port in China, with an annual cargo handling capacity of more than 
Table 1 Description of 16 measured PAH concentration in the surface soils

\begin{tabular}{|c|c|c|c|c|c|c|c|c|}
\hline$\overline{\mathrm{PAHs}}$ & $\begin{array}{l}\text { Number } \\
\text { of rings }\end{array}$ & $\begin{array}{l}\text { Min. } \\
\left(\operatorname{ng~g~}^{-1}\right)\end{array}$ & $\begin{array}{l}\text { Max. } \\
\left(\operatorname{ng~g~}^{-1}\right)\end{array}$ & $\begin{array}{l}\text { Aver. } \\
\left(\text { ng g }^{-1}\right)\end{array}$ & $\begin{array}{l}\text { Mid. } \\
\left(\mathrm{ng} \mathrm{g}^{-1}\right)\end{array}$ & $\begin{array}{l}\text { Std. } \\
\left(\operatorname{ng~g~}^{-1}\right)\end{array}$ & $\mathrm{CV} \%$ & DR \% \\
\hline Nap & 2 & $\mathrm{ND}$ & 613 & 152 & 125 & 131 & 86.7 & 89.4 \\
\hline Acy & 3 & ND & 0.00 & 0.00 & 0.00 & 0.00 & 0.00 & 0.00 \\
\hline Ace & 3 & ND & 37.5 & 2.09 & 0.00 & 7.38 & 354 & 9.62 \\
\hline $\mathrm{Fl}$ & 3 & ND & 107 & 20.7 & 16.6 & 19.7 & 95.1 & 89.4 \\
\hline Phe & 3 & ND & 941 & 73.8 & 47.8 & 101 & 137 & 95.2 \\
\hline An & 3 & ND & 261 & 36.2 & 21.5 & 47.3 & 131 & 80.8 \\
\hline Flu & 4 & ND & 364. & 57.7 & 39.7 & 67.5 & 117 & 99.0 \\
\hline Pyr & 4 & 1.25 & 498 & 48.8 & 29.9 & 68.8 & 141 & 100 \\
\hline $\mathrm{BaA}^{\mathrm{a}}$ & 4 & ND & 574 & 40.6 & 9.29 & 88.1 & 217 & 77.9 \\
\hline $\mathrm{Chr}^{\mathrm{a}}$ & 4 & 2.82 & 529 & 62.0 & 30.0 & 77.7 & 125 & 100 \\
\hline $\mathrm{BbF}^{\mathrm{a}}$ & 5 & ND & 517 & 64.3 & 33.8 & 83.3 & 129 & 91.3 \\
\hline $\mathrm{BkF}^{\mathrm{a}}$ & 5 & ND & 813 & 48.6 & 15.2 & 97.3 & 200 & 97.1 \\
\hline $\mathrm{BaP}^{\mathrm{a}}$ & 5 & ND & 371 & 53.2 & 20.3 & 67.4 & 126 & 97.1 \\
\hline $\operatorname{Inp}^{\mathrm{a}}$ & 6 & ND & 4,380 & 55.2 & 25.0 & 67.3 & 122 & 95.2 \\
\hline $\mathrm{DBA}^{\mathrm{a}}$ & 5 & ND & 216 & 34.1 & 0.670 & 52.0 & 152 & 95.2 \\
\hline $\mathrm{BgP}$ & 6 & ND & 884 & 65.3 & 21.4 & 102 & 156 & 95.2 \\
\hline$\sum 7$ PAHscarc ${ }^{\mathrm{b}}$ & & 22.0 & 3,330 & 358 & 176 & 475 & 133 & 100 \\
\hline$\sum 16 \mathrm{PAHs}^{\mathrm{c}}$ & & 68.7 & 5,990 & 814. & 553 & 813 & 99.8 & 100 \\
\hline
\end{tabular}

${ }^{\mathrm{a} C a r c i n o g e n i c ~} \mathrm{PAH}$ compounds

${ }^{\mathrm{b}}$ Sum concentration of seven carcinogenic PAH compounds

'Sum concentration of $16 \mathrm{PAH}$ compounds

$N D$ not detectable, $C V$ coefficient of variation, $D R$ detectable ratio

258 million tons in 2006. The port has container docks, and receives shipments of mineral ore, petroleum, and coal, which explains the relatively high PAHs concentrations at this site.

Total PAH concentrations of the other 104 topsoil samples ranged from 68.7 to $5,990 \mathrm{ng} \mathrm{g}^{-1}$ d. w., with an average of $814 \mathrm{ng} \mathrm{g}^{-1}$. The site with the highest PAH level of the 104 topsoil samples was located at Dagu Chemical Industry
Park in Tanggu District. In comparison with the results of previous research (Table 2), total PAHs concentrations of this area were lower than those reported in the urban soil of Beijing (219$27,825 \mathrm{ng} \mathrm{g}^{-1}$; Tang et al. 2005) and Dalian (219$18,727 \mathrm{ng} \mathrm{g}^{-1}$; Wang et al. 2007) in China. The levels were also lower than that in some developed areas, such as in Estonian urbanized areas (2200-12,300 $\mathrm{ng} \mathrm{g}^{-1}$; Trapido 1999) and the urban
Table 2 Comparison of PAH concentrations (ng $\mathrm{g}^{-1}$ d.w.) in surface soil of different region

$N A$ not available

${ }^{\mathrm{a}}$ The median value of the concentration

\begin{tabular}{llll}
\hline Locations & Average & Maximum & References \\
\hline Estonian urbanized areas & NA & 12,300 & Trapido (1999) \\
Detroit River, USA & NA & $17.5-43,800$ & Kannan et al. (2001) \\
Urban soils of New Orleans USA & $3,731^{\mathrm{a}}$ & 40,692 & Mielke et al. (2001) \\
South Korea & 236 & 2,834 & Nam et al. (2003) \\
Tianjin, China & 839 & 5,190 & Duan et al. (2005) \\
Tanggu-Hangu area & 2,430 & 5,190 & Duan et al. (2005) \\
Urban soil in Beijing, China & 3,917 & 27,825 & Tang et al. (2005) \\
Yangtze River Delta, China & 397 & 3,881 & Ping et al. (2006) \\
Hongkong, China & 54.6 & 410 & Zhang et al. (2006) \\
Vegetable fields of the Pearl River & NA & 3,700 & Cai et al. (2007) \\
$\quad$ River Delta, China & & & \\
Dalian, China & 1,104 & 18,727 & Wang et al. (2007) \\
Tianjin Binhai New Area, China & 814 & 5,990 & This study \\
\hline
\end{tabular}


center of New Orleans USA (647-40,692 $\mathrm{ng} \mathrm{g}^{-1}$; Mielke et al. 2001), and the Detroit River (17.543,800 $\mathrm{ng} \mathrm{g}^{-1}$ ), USA (Kannan et al. 2001). The levels were close to those found in vegetable field soils of the Pearl River Delta (160-3,700 ng g ${ }^{-1}$; Cai et al. 2007) and soils from Tianjin (199$5,190 \mathrm{ng} \mathrm{g}^{-1}$; Duan et al. 2005) but higher than those found in soils in other areas of China, such as Hong Kong (7.0-410 $\mathrm{ng} \mathrm{g}^{-1}$; Zhang et al. 2006) and the Yangtze River Delta (8.9-3881 ng g ${ }^{-1}$; Ping et al. 2006), and agricultural soils (23.3-2834) in South Korea (Nam et al. 2003).
However, the concentrations of PAHs from TBNA were lower than the levels reported by Duan et al. (2005; 2,430 ng g ${ }^{-1}$, mean) in six sites from Tanggu-Hangu area. The main difference was in the levels of Nap (822 $\mathrm{ng} \mathrm{g}^{-1}$, mean), Phe (325 $\mathrm{ng} \mathrm{g}^{-1}$, mean), Flu (316 $\mathrm{ng} \mathrm{g}^{-1}$, mean), and Pyr (220 ng g ${ }^{-1}$, mean), which were higher than the levels in this study. This change was probably due to the considerable variation in the spatial distribution of PAHs in this area. Organic carbon content may influence levels of PAHs, but we have not measured organic carbon in the soils. In
Fig. 2 Distribution map of total PAH concentrations in soils from Tianjin Binhai New Area

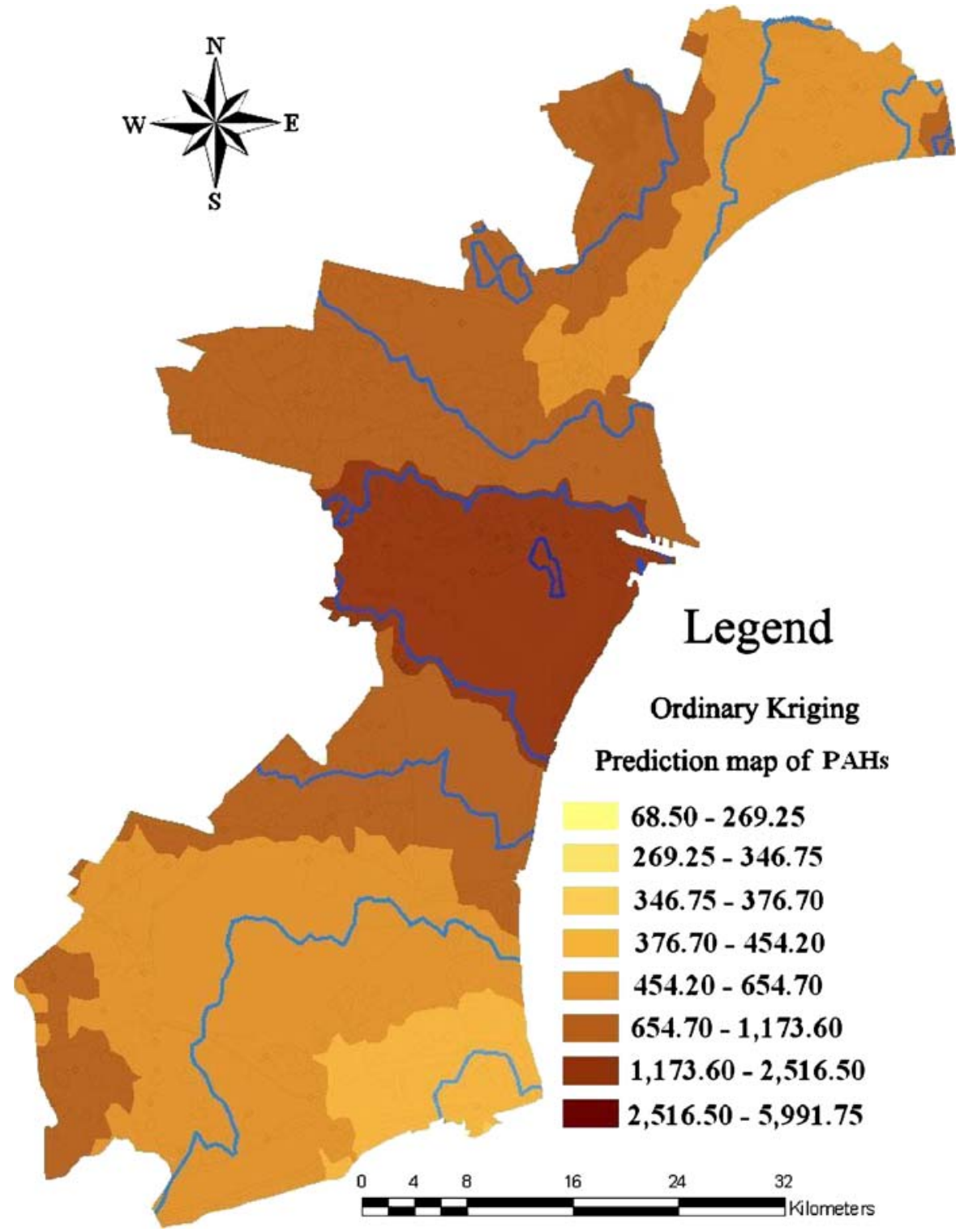


general, concentrations of PAHs in typical surface soils in TBNA were at mid to high levels compared with the other areas, especially those in China.

Spatial distribution of PAHs

The spatial distribution of total PAH concentrations in relation to geographic locations is shown in Fig. 2 and Table 3. The sites with high concentrations in Hangu and Tanggu are mainly distributed around the chemical industry park, such as Hangu and Dagu chemical industry parks. $\sum 16$ PAH concentrations in soils of Dagu chemical industry parks were higher than those found in soils around Hangu chemical industry parks. This is mainly because there are more factories with coal as main fuel and longer history in Dagu chemical industry parks than in Hangu chemical industry parks. Hangu chemical industry parks also enforced more stringent pollution control measures than Dagu chemical industry parks. Industrial development has negatively influenced the environment around these areas and remains a health risk, which requires further attention. Traffic is another important contributor to $\mathrm{PAH}$ contamination in Tanggu. Some sites with high concentration were near highways in Tanggu. Except for a few sites near petro-chemical factories, most sites from Dagang are located in the countryside and showed relatively low PAH concentrations.

PAH concentrations in TBNA are closely linked to the industrialization in and around the area. The most industrialized district, Tanggu, had the highest total PAH concentrations (1,150 $\left.\mathrm{ng} \mathrm{g}^{-1}\right)$, followed by Hangu (657.67 $\mathrm{ng} \mathrm{g}^{-1}$ ) and Dagang (573.34 $\mathrm{ng} \mathrm{g}^{-1}$ ), which suggests that Tanggu district is more seriously contaminated by PAHs, compared with Hangu and Dagang districts. This finding agrees with reports that rural soils usually have lower PAH concentrations than urban or industrial ones (Trapido 1999; Wilcke 2000; Zhang et al. 2006; Cai et al. 2007).

PAH concentrations in soil samples from TBNA are also associated with population density. The higher the population density is, the higher the concentration of total PAHs in soils and sediments around the region (Kannan et al. 2005). Accompanied by the acceleration of urbanization and industrialization, population in Tanggu and Dagang has increased in the past

Table 3 Profiles of PAHs in each district (ng g $\mathrm{g}^{-1}$ d.w.)

\begin{tabular}{|c|c|c|c|c|c|c|c|c|c|}
\hline \multirow[t]{2}{*}{ PAHs } & \multicolumn{4}{|c|}{ Hangu(38 $\left(38^{a}\right.$} & \multicolumn{3}{|l|}{ Tanggu(38) } & \multicolumn{2}{|l|}{ Dagang(38) } \\
\hline & Range & Mean & Median & Range & Mean & Median & Range & Mean & $\overline{\text { Median }}$ \\
\hline Nap & ND-409 & $135\left(117^{\mathrm{b}}\right)$ & 119 & ND-613 & $208(158)$ & 153 & ND-258 & $96.9(67.9)$ & 95.3 \\
\hline Ace & ND-ND & ND & ND & ND-37.5 & $5.71(11.4)$ & ND & ND-ND & ND & 0.00 \\
\hline $\mathrm{Fl}$ & ND-106 & $22.9(23.1)$ & 20.7 & ND-68.8 & $21.1(19.0)$ & 13.9 & ND-64.5 & $17.3(15.3)$ & 16.3 \\
\hline Phe & ND-226 & $53.7(46.2)$ & 45.8 & ND-941 & 107 (156) & 56.2 & ND-112 & $56.1(20.9)$ & 51.4 \\
\hline An & ND-164 & $28.9(37.1)$ & 21.6 & ND-261 & $39.9(61.4)$ & 14.1 & ND-138 & $41.0(36.9)$ & 47.5 \\
\hline Flu & ND-351 & $44.0(58.1)$ & 28.6 & $2.69-364$ & $87.8(84.0)$ & 60.7 & $5.47-162$ & $35.4(32.4)$ & 24.5 \\
\hline Pyr & $3.29-278$ & $33.0(46.4)$ & 18.5 & $1.25-498$ & $78.1(92.7)$ & 51.5 & $1.84-193$ & $30.4(37.8)$ & 18.7 \\
\hline $\mathrm{BaA}$ & ND-325 & $33.6(73.2)$ & 9.29 & ND-574 & 68.5 (117) & 18.5 & ND-207 & $12.2(38.4)$ & 4.35 \\
\hline Chr & $3.54-243$ & $44.4(52.1)$ & 20.1 & $2.82-529$ & 95.2 (104) & 76.2 & $3.41-168$ & $40.6(44.3)$ & 19.0 \\
\hline $\mathrm{BbF}$ & ND-467 & $58.1(79.9)$ & 28.5 & ND-517 & $91.3(103)$ & 61.9 & ND-146 & $36.1(36.4)$ & 19.1 \\
\hline $\mathrm{BkF}$ & ND-412 & $42.5(76.7)$ & 11.1 & ND-813 & 68.5 (137) & 26.8 & $3.40-156$ & $29.9(34.9)$ & 12.3 \\
\hline $\mathrm{BaP}$ & ND-360 & $45.9(67.1)$ & 14.5 & ND-371 & $75.0(75.5)$ & 52.1 & ND-151 & $33.8(47.0)$ & 7.29 \\
\hline Inp & ND-438 & $46.8(74.9)$ & 16.9 & ND-306 & $74.9(68.2)$ & 48.4 & ND-162 & $40.0(48.4)$ & 12.5 \\
\hline DBA & ND-119 & $28.4(41.5)$ & ND & ND-216 & $44.8(58.8)$ & 7.01 & ND-178 & $27.4(54.3)$ & ND \\
\hline $\mathrm{BgP}$ & ND-148 & $40.7(49.0)$ & 17.0 & ND-290 & $82.0(68.7)$ & 56.4 & ND-884 & $76.1(168)$ & 15.2 \\
\hline$\sum \mathrm{PAHs}_{\mathrm{carc}}$ & $29.5-2,290$ & $300(418)$ & 164 & $22.0-3,330$ & $518(599)$ & 329 & $31.0-965$ & $220(254)$ & 101 \\
\hline$\sum \mathrm{PAHs}$ & $104-3,370$ & $658(593)$ & 479 & $68.7-5,990$ & $1,150(1,080)$ & 941 & $179-1,740$ & $573(418)$ & 384 \\
\hline
\end{tabular}

${ }^{\text {a Number of samples }}$

bStandard deviation 
decade. Population density in Hangu, Tanggu, and Dagang in 2006 was 381, 652, and 278 people $/ \mathrm{km}^{2}$, respectively. There are more people, and more human activity and more waste discharge in these districts, which is probably one of the important reasons for heavy PAHs contamination.

To place the current concentrations of PAHs into ecological perspective, we compared the surface soil concentrations determined with threshold effect concentrations. The threshold values of this classification (unpolluted $\left(<200 \mathrm{ng} \mathrm{g}^{-1}\right)$; weakly polluted (200-600 $\mathrm{ng} \mathrm{g}^{-1}$ ); moderately polluted (600-1,000 $\left.\mathrm{ng}^{-1}\right)$; severely polluted $\left(>1,000 \mathrm{ng} \mathrm{g}^{-1}\right.$ ) were derived from the results of an investigation of PAHs in European agricultural soils, as well as from an estimation of risks of human exposure (Paterson and McKay 1989; Maliszewska-Kordybach 1996). According to this classification, 93 soil samples would be considered as at least weakly contaminated with PAHs (>200 $\mathrm{ng} \mathrm{g}^{-1}$ ), indicating potential health risk to humans. Twenty-five samples fall into the "heavily contaminated" class, which are mainly distributed around the chemical industry parks.

PAHs are of great concern mainly because of their documented carcinogenicity. The USEPA considers $\mathrm{BaA}, \mathrm{Chr}, \mathrm{BbF}, \mathrm{BkF}, \mathrm{BaP}$, Inp, and DBA as potentially carcinogenic PAHs. Concentrations of seven carcinogenic PAHs ( 7PAHscarc) varied from 22 to $3,326 \mathrm{ng} \mathrm{g}^{-1}$ d.w., with an average of $358 \mathrm{ng} \mathrm{g}^{-1}$, in 104 soils from TBNA. The $\sum 7$ PAHscarc in the Tianjin Port soil sample was $34,829 \mathrm{ng} \mathrm{g}^{-1}$.

Among known potentially carcinogenic PAHs, $\mathrm{BaP}$ is the only $\mathrm{PAH}$ for which toxicological data are sufficient to derive a carcinogenic potency factor (Peters et al. 1999; Villeneuve et al. 2002). Toxic equivalency factors (TEFcarc) were used to quantify the carcinogenicity of other PAHs relative to $\mathrm{BaP}$ and to estimate $\mathrm{BaP}$-equivalent doses (BaPeq dose; Nadal et al. 2004). The calculated TEFcarcs for BaA, Chr, BbF, BkF, BaP, Inp, and DBA are $0.1,0.001,0.1,0.01,1,0.1$, and 1 , respectively, according to the USEPA. In this study, we converted these seven PAH concentrations into one toxic concentration for each site using the corresponding TEFcarc. The total toxic BaP equivalent (TEQcarc) for all PAHs was calculated as:

$\mathrm{TEQ}^{\mathrm{carc}}=\sum C_{\mathrm{i}} \times \mathrm{TEF}_{\mathrm{i}}^{\mathrm{carc}}$

where $C_{i}$ represents the concentration of each carcinogenic PAHs.

The total TEQcarc values of 104 samples varied from 0.58 to $735.73 \mathrm{ng} \mathrm{g}^{-1} \mathrm{~d}$.w., with an average of $105.93 \mathrm{ng} \mathrm{g}^{-1}$. The total TEQcarc value of the Tianjin Port soil was 9,239.4 $\mathrm{ng} \mathrm{g}^{-1}$. The maximum total TEQcarc value of the other 104 soils was found at the site with the highest $\sum 16 \mathrm{PAH}$. The spatial distribution of TEQcarc in relation to geographic locations was shown in Fig. 3. The spatial distribution of TEQcarc was in agreement with the $\sum 16 \mathrm{PAH}$ distribution in the TBNA soil.

\section{Soil PAH Profile and potential sources}

The contribution of individual PAHs to the sum of PAHs concentrations varied greatly among the soil samples (Table 1). Although high molecular weight (HMW) carcinogenic PAHs, such as BbF, $\mathrm{Chr}, \mathrm{BaP}$, Inp, and $\mathrm{BkF}$, were prevalent in samples from most sites, two low molecular weight (LMW) PAHs, Nap and Phe, were the dominant component in the soils from TBNA. These two LMWs accounted for $22.1 \%$ and $10.7 \%$, respectively, of the $\sum$ PAHs concentration, which is close to the proportions in water and sediments from this area (Shi et al. 2005). Normally, high molecular weight PAHs such as benzo[b $+\mathrm{j}+\mathrm{k}]$ fluoranthene, Chr, Flu and Pyr are dominant in the soils investigated (Wilcke 2000). The different PAHs profiles fingerprint in TBNA suggests a different source pattern. Recent literature found strong indications that Nap and Phe were produced, not only in exhaust fumes, but also biologically and in spills of unburnt petroleum (Aislabie et al. 1999; Wilcke et al. 2003). Oil wells in TBNA are probably an important source of LMW PAHs, including Nap and Phe, and biological processes are probably another source of LMW PAHs, which will be further studied. It is well accepted that LMW PAHs predomination suggests either a local source of 
PAHs or a relatively recent introduction of these chemicals (Shi et al. 2005).

Results of correlation analysis showed that significant correlations existed among all the 16 PAHs in Tanggu, while significant correlation existed only among PAHs with 4-5 rings in Hangu and Dagang. The LMW PAHs (2-3 rings) from Hangu and Dagang did not correlate with HMW PAHs (4-5 rings). Significant correlation among PAHs suggested that they originated from similar sources and the sources were located in close proximity to the sampling locations (Chung et al. 2007). The fact that the low molecular mass PAHs (2-3 rings) did not correlate with the higher molecular mass PAHs (4-5 rings) in Hangu and Dagang suggests that the principal sources of PAHs in soil in these areas were from remote sites by medium to long-range atmospheric deposition. This implies that the PAHs in undeveloped area are most likely derived from other areas. In com-
Fig. 3 Distribution map of TEQcarc in soils from Tianjin Binhai New Area

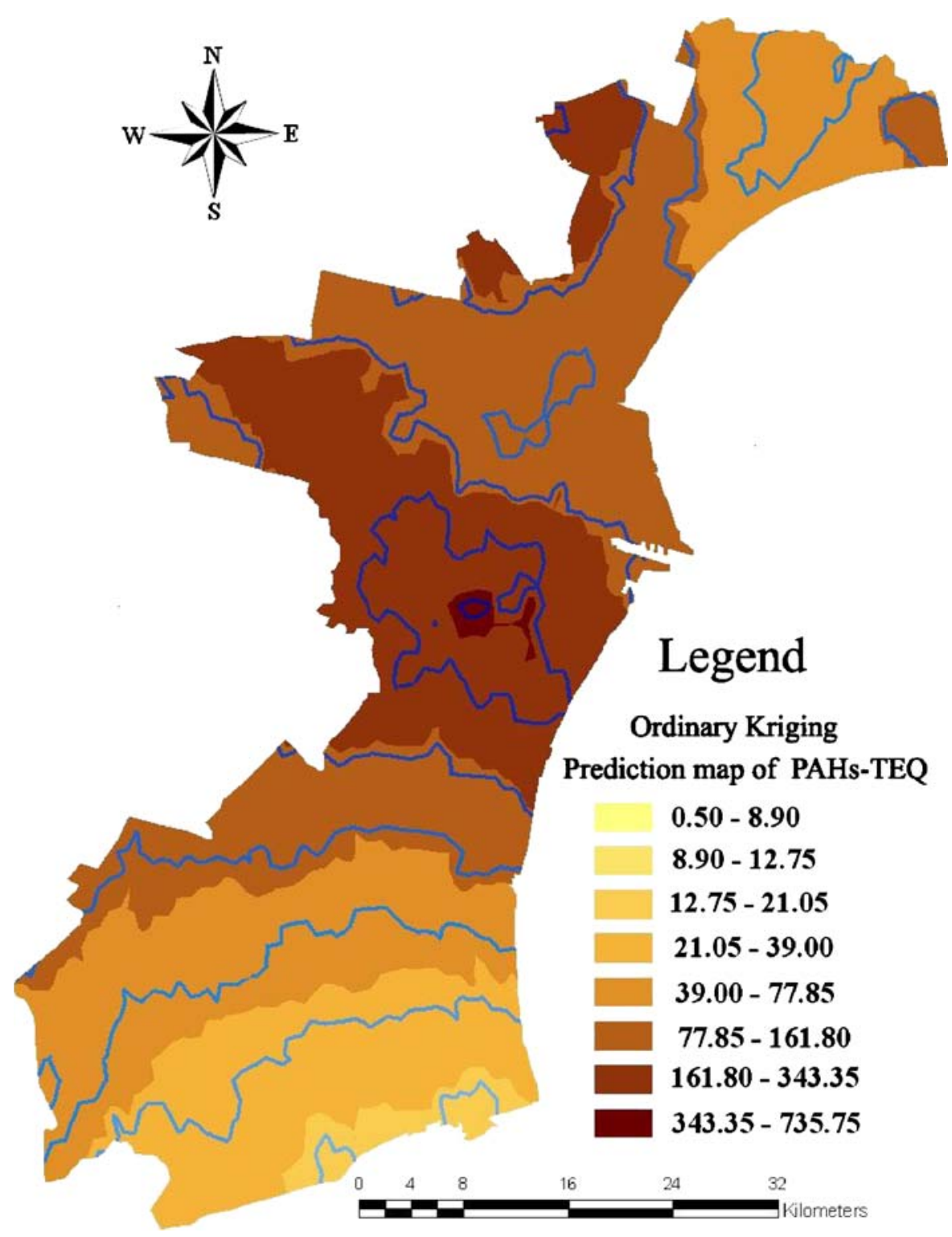


Table 4 Special ratios of PAH sources

Budzinski et al. 1997; Yunker et al. 2002)

\begin{tabular}{lll}
\hline Molecular ratio & Range & Sources \\
\hline Flu/(Flu + Pyr $)$ & $<0.4$ & Petroleum input \\
& $0.4-0.5$ & Liquid fossil fuel combustion \\
& $>0.5$ & Grass, wood or coal combustion \\
$\mathrm{BaA} /(\mathrm{BaA}+\mathrm{Chr})$ & $<0.2$ & Petroleum input \\
& $0.2-0.35$ & Mixture of petroleum and combustion \\
& $>0.35$ & Combustion \\
\hline
\end{tabular}

parison, PAHs in most soils from Tanggu may be derived from similar sources in close proximity to the sampling locations.

Molecular indices based on the ratios of individual PAH levels in soil can be used to distinguish PAHs from pyrogenic (e.g., fossil fuel combustion and vegetation fires) and petroleum (e.g., oil spill and petroleum products) inputs. Two specific $\mathrm{PAH}$ ratios were calculated for the studied samples: Flu/(Flu + Pyr) and BaA/(BaA + Chr), which have been frequently employed in published studies (Budzinski et al. 1997; Khim et al. 1999; Yunker et al. 2002). Table 4 shows these ratios in sources of PAHs. According to Fig. 4 and Table 4, in most sites, the values of the Flu/(Flu + Pyr) ratios are above 0.5, which indicates grass, wood, or coal combustion were the main PAHs sources in this area. However, several sites from Tanggu than Hangu and Dagang fell in the range of $0.4-0.5$, which suggests that liquid fossil fuel combustion has significant influence on Tanggu than on Hangu and Dagang.

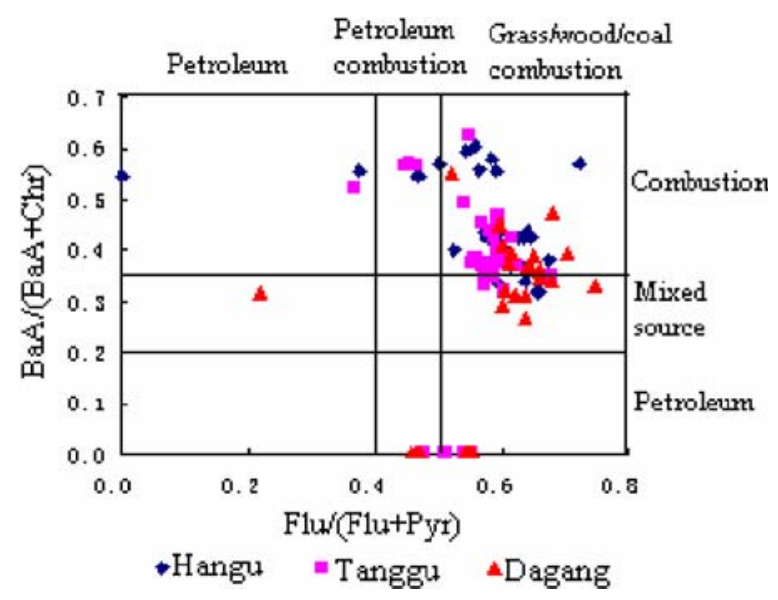

Fig. 4 Plots of PAH index pair ratios for source identification
Most of the values of the $\mathrm{BaA} /(\mathrm{BaA}+\mathrm{Chr})$ ratios are above 0.35 , which indicates combustion is the main source of PAHs in this area. More values of the $\mathrm{BaA} /(\mathrm{BaA}+\mathrm{Chr})$ ratios from Tanggu and Dagang are below 0.35 than from Hangu, which suggests that petroleum input is more common in Dagang and Tanggu than in Hangu. Factories in Hangu and Dagu Chemical Industry Parks, and house heating in winter may be the sources of PAHs arising from coal combustion. Straw stalk burned in open areas after harvest in TBNA, especially in Dagang and Hangu, may be a source of PAHs derived from biomass combustion. Tanggu has more vehicles and more highways than Hangu and Dagang, which is probably the main reason that liquid fossil fuel combustion has more influence on Tanggu than Hangu and Dagang. In comparison to Hangu, Tanggu, and Dagang have more oil wells and oil refineries, which could explain why petroleum input is higher in Dagang and Tanggu than in Hangu.

In general, house-heating in winter, straw stalk burning in open areas after harvest, and petroleum input are the main sources of PAHs at most sites away from the point sources in TBNA. However, factory discharge and vehicle exhaust are the major sources around industrial parks and near highways. Biological processes are probably another source of low molecular weight PAHs, which requires further study.

\section{Conclusion}

There existed medium to high level of PAHs contamination in TBNA, where concentrations of PAHs in 104 soil samples ranged from 68.7 to $5,590 \mathrm{ng} \mathrm{g}^{-1} \mathrm{~d}$. w. with a mean of $\sum 16$ PAHs $814.15 \pm 812.87 \mathrm{ng} \mathrm{g}^{-1}$. The concentration of $\sum 16$ PAHs in one soil sample from Tianjin Port 
was exceptionally high $\left(48,700 \mathrm{ng} \mathrm{g}^{-1}\right)$. Two LMW PAHs, Nap and Phe, were the dominant components in soil samples, which accounted for $22.10 \%$ and $10.67 \%$ of $\sum 16$ PAHs concentrations. Eightynine percent of the 105 soil samples were considered to be at least less contaminated with PAHs $\left(>200 \mathrm{ng} \mathrm{g}^{-1}\right.$ ) and $24 \%$ were heavily polluted (>1,000 $\mathrm{ng} \mathrm{g}^{-1}$ ). Sixty-eight percent of heavily polluted samples are from Tanggu district, revealing that this district was heavily contaminated by PAHs. In comparison, Hangu was moderately contaminated while Dagang was less contaminated. The sites with high PAH concentrations are mainly distributed around the chemical industry parks and near highways. House heating in winter, straw stalk combustion in the open areas after harvest, and petroleum input were the common sources of PAHs in TBNA, while factory discharge and vehicle exhaust were the major sources around the chemical industrial parks and near highways.

Acknowledgements This study was supported by the National Basic Research Program of China ('973' Research Program) with Grant No.2007CB407307, the Knowledge Innovation Program of the Chinese Academy of Sciences with Grant No.KZCX2-YW-420-5, and the Special Funds for Young Scholars of RCEES with Grant No.RCEESQN-200707. The authors are grateful to Dr Donghong Wang, Dr Yiping Xu and Dr Shengguang Yuan from the State Key Laboratory of Environmental Aquatic Chemistry, Research Center for Eco-Environmental Sciences for their assistance in chemical analyses. We would also like to thank Professor Kurunthachalam Kannan for his constructive comments and language polish.

\section{References}

Aislabie, J., Balks, M., Astori, N., Stevenson, G., \& Symons, R. (1999). Polycyclic aromatic hydrocarbons in fuel-oil contaminated soils, Antarctica. Chemosphere, 39, 2201-2207. doi:10.1016/S0045-6535 (99)00144-7.

Budzinski, H., Jones, I., Bellocq, J., Pierard, C., \& Garrigues, P. (1997). Evaluation of sediment contamination by polycyclic aromatic hydrocarbons in the Gironde estuary. Marine Chemistry, 58, 85-97. doi:10.1016/S0304-4203(97)00028-5.

Cai, Q. Y., Mo, C. H., Li, Y. H., Zeng, Q. Y., Katsoyiannis, A., Wu, Q. T., et al. (2007). Occurrence and assessment of polycyclic aromatic hydrocarbons in soils from vegetable fields of the Pearl River Delta, South China. Chemosphere, 68, 159-168. doi:10.1016/j. j.chemosphere.2006.12.015.

Chung, M. K., Hu, R., Cheung, K. C., \& Wong, M. H. (2007). Pollutants in Hong Kong soils: Polycyclic aromatic hydrocarbons. Chemosphere, 67, 464-473. doi:10.1016/j.chemosphere.2006.09.062.

Cousins, I. T., Beck, A. J., \& Jones, K. C. (1999). A review of the processes involved in the exchange of semivolatile organic compounds (SVOC) across the air-soil interface. The Science of the Total Environment, 228, 5-24. doi:10.1016/S0048-9697(99)00015-7.

Duan, Y. H., Tao, S., Wang, X. J., Li, B. G., Xu, F. L., Liu, W. X., et al. (2005). Spatial distribution and sources of PAHs in Tianjin's topsoil. Acta Pedol Sin, 42, 942-947. (in Chinese).

Edwards, N. T. (1983). Polycyclic aromatic hydrocarbons (PAHs) in the terrestrial environment-a revIew. Journal of Environmental Quality, 12, 427-441.

Kannan, K., Kober, J. L., Kang, Y. S., Masunaga, S., Nakanishi, J., Ostaszewski, A., et al. (2001). Polychlorinated-naphthalenes, -biphenyls, -dibenzop-dioxins, -dibenzofurans, polycyclic aromatic hydrocarbons and alkylphenols in sediment from the Detroit and Rouge Rivers, Michigan, USA. Environmental Toxicology and Chemistry, 20, 1878-1889. doi:10.1897/ 1551-5028(2001)020<1878:PNBDPD>2.0.CO;2.

Kannan, K., Restrepo, B. J., Yohn, S. S., Giesy, J. P., \& Long, D. T. (2005). Spatial and temporal distribution of polycyclic aromatic hydrocarbons in sediments from Michigan inland lakes. Environmental Science \& Technology, 39, 4700-4706. doi:10.1021/ es050064f.

Khim, J. S., Kannan, K., Villeneuve, D. L., Koh, C. H., \& Giesy, J. P. (1999). Characterization and distribution of trace organic contaminants in sediment from Masan Bay, Korea: 1. Instrumental analysis. Environmental Science \& Technology, 33, 4199-4205. doi:10.1021/ es9904484.

Kipopoulou, A. M., Manoli, E., \& Samara, C. (1999). Bioconcentration of polycyclic aromatic hydrocarbons I vegetables grown in an industrial area. Environmental Pollution, 106, 369-380. doi:10.1016/ S0269-7491(99)00107-4.

Maliszewska-Kordybach, B. (1996). Polycyclic aromatic hydrocarbons in agricultural soils in Poland: Preliminary proposals for criteria to evaluate the level of soil contamination. Applied Geochemistry, 11, 121127. doi:10.1016/0883-2927(95)00076-3.

Mielke, H. W., Wang, G., Gonzales, C. R., Le, B., Quach, V. N., \& Mielke, P. W. (2001). PAH and metal mixtures in New Orleans soils and sediments. The Science of the Total Environment, 281, 217-227. doi:10.1016/S0048-9697(01)00848-8.

Nadal, M., Schuhmacher, M., \& Domingo, J. L. (2004). Levels of PAHs in soil and vegetation samples from Tarragona County, Spain. Environmental Pollution, 132, 1-11. doi:10.1016/j.envpol.2004.04.003.

Nam, J. J., Song, B. H., Eom, K. C., Lee, S. H., \& Smith, A. (2003). Distribution of polycyclic aromatic hydrocarbons in agricultural soils in South Korea. 
Chemosphere, 50, 1281-1289. doi:10.1016/S00456535(02)00764-6.

Paterson, S., \& McKay, D. (1989). A model illustrating the environmental fate, exposure and human uptake of persistent organic chemicals. Ecological Modelling, 47, 85-114. doi:10.1016/0304-3800(89)90111-7.

Peters, C. A., Knightes, C. D., \& Brown, D. G. (1999). Long-term composition dynamics of PAH-containing NAPLs and implications for risk assessment. Environmental Science \& Technology, 33, 4499-4507. doi:10.1021/es981203e.

Ping, L. F., Luo, Y. M., Zhang, H. B., Li, Q. B., \& Wu, L. H. (2006). Distribution of polycyclic aromatic hydrocarbons in thirty typical soil profiles in the Yangtze River Delta region, east China. Environmental Pollution, 147, 1-8.

Shi, Z., Tao, S., Pan, B., Fan, W., He, X. C., Zuo, Q., et al. (2005). Contamination of rivers in Tianjin, China by polycyclic aromatic hydrocarbons. Environmental Pollution, 134, 97-111. doi:10.1016/j.envpol.2004. 07.014.

Tang, L. L., Tang, X. Y., Zhu, Y. G., Zheng, M. H., \& Miao, Q. L. (2005). Contamination of polycyclic aromatic hydrocarbons (PAHs) in urban soils in Beijing, China. Environment International, 31, 822-828. doi:10. 1016/j.envint.2005.05.031.

Trapido, M. (1999). Polycyclic aromatic hydrocarbons in Estonian soil: Contamination and profiles. Environmental Pollution, 105, 67-74. doi:10.1016/S02697491(98)00207-3.

Villeneuve, D. L., Khim, J. S., Kannan, K., \& Giesy, J. P. (2002). Relative potencies of individual polycyclic aromatic hydrocarbons to induce dioxinlike and estrogenic responses in three cell lines.
Environmental Toxicology, 17, 128-137. doi:10.1002/ tox.10041.

Wang, Z., Chen, J. W., Qiao, X. L., Yang, P., Tian, F. L., \& Huang, L. P. (2007). Distribution and sources of polycyclic aromatic hydrocarbons from urban to rural soils: A case study in Dalian, China. Chemosphere, 68, 965-971. doi:10.1016/j.chemosphere.2007.01.017.

Wilcke, W. (2000). Polycyclic aromatic hydrocarbons (PAHs) in soil-a review. Journal of Plant Nutrition and Soil Science, 163, 229-248. doi:10.1002/15222624(200006)163:3<229::AID-JPLN229>3.0.CO;2-6.

Wilcke, W. (2007). Global patterns of polycyclic aromatic hydrocarbons (PAHs) in soil. Geoderma, 141, 157166. doi:10.1016/j.geoderma.2007.07.007.

Wilcke, W., Amelung, W., Krauss, M., Martius, C., Bandeira, A., \& Garcia, M. (2003). Polycyclic aromatic hydrocarbon (PAH) patterns in climatically different ecological zones of Brazil. Organic Geochemistry, 34, 1405-1417. doi:10.1016/S0146-6380(03)00137-2.

Wu, S. P., Tao, S., Xu, F. L., Dawson, R., Lan, T., Li, B. G., et al. (2005). Polycyclic aromatic hydrocarbons in dustfall in Tianjin, China. The Science of the Total Environment, 345, 115-126. doi:10.1016/j.scitotenv.2004. 11.003.

Yunker, M. B., Macdonald, R. W., Vingarzan, R., Mitchell, R. H., Goyette, D., \& Sylvestre, S. (2002). PAHs in the Fraser River Basin: A critical appraisal of $\mathrm{PAH}$ ratios as indicators of $\mathrm{PAH}$ source and composition. Organic Geochemistry, 33, 489-515. doi:10.1016/S0146-6380(02)00002-5.

Zhang, H. B., Luo, Y. M., Wong, M. H., Zhao, Q. G., \& Zhang, G. L. (2006). Distribution and concentrations of PAHs in Hong Kong soils. Environmental Pollution, 141, 107-114. doi:10.1016/j.envpol.2005.08.031. 